\title{
IMPLEMENTASI PENDIDIKAN KARAKTER MELALUI MEDIA FILM DALAM PEMBELAJARAN AKIDAH AKHLAK
}

(Penelitian Deskriptif Kualitatif di Kelas VIII MTs. Miftahul ‘Ulum Dan MTs. AsySyifa Kecamatan Cipatat Kabupaten Bandung Barat)

\section{IMPLEMENTATION OF CHARACTER EDUCATION THROUGH FILM MEDIA IN THE LEARNING OF MORAL FAITH}

Qualitative Descriptive Research in Class VIII MTs. Miftahul 'Ulum and MTs. Asy-Syifa District Cipatat West Bandung Regency

\author{
Arip Muhazir \\ e-mail : aripmuhazir021281@gmail.com \\ Universitas Islam Nusantara Bandung \\ Badruzzaman M. Yunus \\ e-mail : badr.yunus55@gmail.com \\ Universitas Islam Nusantara Bandung \\ Asep A. Fathurrohman \\ e-mail : asepahmadfathurrohman79@gmail.com \\ Universitas Islam Nusantara Bandung \\ Wati Karmila \\ e-mail :ddntaufiq1@gmail.com \\ STAIDA Muhamadiyah Garut
}

\begin{abstract}
Abstrak
Penelitian ini dilatarbelakangi bahwa derasnya arus informasi, hiburan dan media sosial mempengaruhi gaya hidup dan pembentukan karakter siswa. Rendahnya motivasi pendidik untuk meningkatkan kompetensi dan keterampilan pada penguasaan teknologi sebagai media pembelajaran juga menjadi salah satu penyebab permasalahan ini. Penelitian ini bertujuan menjelaskan implementasi pendidikan karakter melalui media film dalam pembelajaran akidah akhlak. Penelitian ini bersifat deskripsi kualitatif, dengan menggunakan pendekatan studi kasus di kelas VIII MTs. Miftahul ‘Ulum dan MTs. Asy-Syifa Kecamatan Cipatat Kabupaten Bandung Barat. Penulis menggunakan metode observasi, wawancara/interview, dokumentasi. Adapun teknik analisis data dengan menggunakan teknik reduksi data, penyajian data, dan kesimpulan Hasil dari penelitian ini, menggambarkan bahwa Pemanfaatan pembelajaran dengan menggunakan multimedia menjadi suatu solusi dalam peningkatan kualitas pembelajaran yang dilakukan di kelas, dan menjadi suatu alternatif mengatasi keterbatasan kesempatan mengajar yang dilaksanakan pendidik. Fungsi multimedia pembelajaran sebagai sumber belajar yakni penyalur, penyampai, penghubung,dan lainlain. Multimedia pembelajaran sebagai penghubung pembelajaran mampu
\end{abstract}


mengefektifkan proses komunikasi sehingga tercapai tujuan yang diinginkan yaitu degan adanya perubahan tingkah laku siswa.

\title{
Kata Kunci: Implementasi, Media Film, Karakter, Aqidah Akhlak
}

\begin{abstract}
This research is motivated by the rapid flow of information, entertainment and social media affecting the lifestyle and character formation of students. The low motivation of educators to improve competence and skills in the mastery of technology as a medium of learning is also one of the causes of this problem. This research aims to explain the implementation of character education through film media in moral learning. This research is a qualitative description, using a case study approach in class VIII MTs. Miftahul 'Ulum and MTs. Asy-Syifa District Cipatat West Bandung Regency. The author uses observation methods, interviews/ interviews, documentation. Data analysis techniques using data reduction techniques, data presentation, and conclusions The results of this study, illustrate that the utilization of learning using multimedia becomes a solution in improving the quality of learning carried out in the classroom, and becomes an alternative to overcoming the limitations of teaching opportunities implemented by educators. The function of multimedia learning as a source of learning is channeling, presenter, liaison, and others. Multimedia learning as a learning link is able to streamline the communication process so that the desired goal is achieved by changes in student behavior.
\end{abstract}

Keywords: Implementation, Film Media, Characters, Aqidah Akhlak

Submitted : 09-11-2021 | Accepted: 16-12-2021 | Published : 26-12-2021

\section{PENDAHULUAN}

Perilaku negatif masyarakat Indonesia baik yang terjadi di kalangan pelajar dan mahasiswa maupun kalangan yang lainnya, jelas menunjukan kerapuhan karakter yang cukup parah yang salah satunya disebabkan oleh tidak optimalnya pengembangan pendidikan karakter tidak diserahkan kepada pendidik agama saja, karena pelaksanaan pendidikan karakter harus dipikul oleh semua pihak, termasuk kepala sekolah, para pendidik, staf tata usaha, tukang sapu, penjaga kantin, dan orang tua di rumah.

Implementasi pendidikan karakter tidak cukup hanya dilaksanakan di sekolah dan perguruan tinggi saja, bahkan dalam langkah selanjutnya pendidikan karakter perlu dilaksanakan oleh seluruh lapisan masyarakat, di seluruh instansi pemerintah, ormas, parpol, lembaga swadaya masyarakat, perusahaan dan kelompok masyarakat lainnya. Juga dalam pelaksanaannya, pendidikan karakter tidak dihafal seperti materi ujian. Pendidikan karakter memerlukan peneladanan dan pembiasaan. Pembiasaan untuk berbuat baik, pembiasaan untuk berlaku jujur, tolong menolong, toleransi, malu berbuat curang, malu 
bersikap malas, malu membiarkan lingkungan kotor. Karena karakter tidak terbentuk secara instan, tetapi harus dilatih secara serius, terus menerus dan proporsional agar mencapai bentuk karakter yang ideal.

Undang-undang No. 20 tahun 2003 tentang Sistem Pendidikan Nasional (Sisdiknas) telah menegaskan bahwa "pendidikan nasional berfungsi mengembangkan kemampuan dan membentuk watak serta peradaban bangsa yang bermartabat dalam rangka mencerdaskan kehidupan bangsa, bertujuan untuk berkembangnya potensi peserta didik agar menjadi manusia yang beriman dan bertakwa kepada Tuhan Yang Maha Esa, berakhlak mulia, sehat, berilmu, cakap, kreatif, mandiri, dan menjadi warga negara yang demokratis serta bertanggung jawab".

Pendidikan karakter merupakan isu penting dalam dunia pendidikan yang dewasa ini banyak mendapat perhatian berbagai kalangan. Generasi muda mengalami krisis moralitas dan karakter yang luar biasa seiring dengan perkembangan dan kemajuan zaman. Pendidikan karakter menopang kehidupan berbangsa dan bernegara karena kemajuan bangsa tidak tergantung pada kualitas kognitif, melainkan juga sangat ditentukan oleh kualitas afektif masyarakat. Dengan kata lain, bangsa yang maju tidak ditentukan oleh kecerdasan intelektual semata, tetapi juga sangat dipengaruhi oleh kecerdasan sikap spiritual maupun sikap sosial. Sejak jaman dahulu, masyarakat memandang institusi pendidikan tidak semata-mata untuk keperluan kecerdasan ilmu pengetahuan, melainkan difungsikan pula untuk mendidik generasi yang memiliki karakter, perilaku, dan budi pekerti yang baik dan mulia.

Bagaimana mengintegrasikan nilai-nilai karakter ini dalam pembelajaran, sehingga melahirkan generasi muda yang memiliki kepribadian yang mulia, adalah tantangan dunia pendidikan saat ini. Maka diperlukan strategi yang efektif baik dalam proses penyampaian pesan-pesan moralitas yang menggugah peserta didik maupun strategi lain yang berkaitan dengan kebijakan pemerintah.

Situasi dan kondisi saat ini sangat memperhatikan karena rendahnya karakter diri seseorang akibat pengaruh canggihnya teknologi dan globalisasi, sehingga memungkinkan terjadinya penyimpangan-penyimpangan pada diri individu itu sendiri khususnya di lembaga pendidikan seperti sekarang. Maka dari itu yang melatar belakangi penulis 
mengangkat judul yang berkaitan dengan penerapan pendidikan karakter dalam pembelajaran akidah akhlak adalah sebagai berikut:

Dari berbagai pengamatan dan wawancara yang dilakukan penulis di MTs. Miftahul 'Ulum dan MTs. Asy Syifa Kecamatan Cipatat, penulis menemukan berbagai masalah karakter di antaranya adalah banyak pergaulan siswa yang kurang menunjukan akhlak terpuji di lingkungan masyarakat sekolah khususnya terhadap pegawai sekolah seperti penjaga sekolah dan tukang sapu di sekolah, serta masih banyaknya pergaulan siswa dengan siswi yang tidak sesuai dengan syari'at Islam. Hal tersebut dipengaruhi oleh tayangan televisi dan canggihnya gadget yang dimiliki peserta didik (Wawancara dengan kepala MTs. Miftahul ‘Ulum Kab. Bandung Barat, Ibu Ida Nursanti, SE, S.Pd pada tangal 30 April 2021). Selain masalah yang telah diungkapkan di atas ada banyak masalah karakter yang terjadi pada peserta didik di kelas VIII MTs. Miftahul 'Ulum dan MTs. Asy-Syifa Kecamatan Cipatat Kabupaten Bandung Barat, misalnya kurang dispilin, kurang bertanggung jawab, kurang mandiri, merajalelanya budaya mencontek, motivasi sekolah yang rendah, kurangnya kepercayaan diri, dan terjadinya pelanggaraan tata tertib sekolah. Hal itu disebabkan karena minimnya pengawasan pendidik terhadap anak di Madrasah sehinga berpengaruh terhadap kurang meningkatnya pendidikan karakter yang ada di kelas VIII MTs. Miftahul 'Ulum dan MTs. Asy-Syifa Kecamatan Cipatat Kabupaten Bandung Barat (Wawancara dengan Wakaur Kurikulum MTs . Miftahul ‘Ulum Kecamatan Cipatat Kab. Bandung Barat,Asep Cinta Komara,M.Pd. pada tangal 30 April 2021.). Adanya penerapan pembelajaran Akidah di kelas VIII MTs. Miftahul 'Ulum dan MTs. Asy-Syifa Kecamatan Cipatat Kabupaten Bandung Barat hampir 75\% secara teori telah dinyatakan lulus sesuai dengan kriteria ketuntasan minimum (KKM) (Wawancara dengan Pendidik Akidah Akhlak MTs Miftahul ‘Ulum Kecamatan, Atep Nandang, S.Pd.I. pada tangal 30 April 2021), tetapi pada konteksnya pembelajaran akidah akhlak hanya sebatas teori tidak diaplikasikan dalam kehidupan sehari-hari oleh peserta didik. Sehingga perlu untuk menerapkan pendidikan karakter yang tidak hanya menekankan pada sisi kognitifnya saja melainkan harus mengembangkan sisi afektif dan psikomotorik peserta didik secara keseluruhan.

Dalam hal ini yang mempunyai peranan penting dalam proses penanaman nilai-nilai 
karakter pada kelas VIIII MTs. Miftahul 'Ulum dan MTs. Asy-Syifa Kecamatan Cipatat Kabupaten Bandung Barat adalah pendidik. Karena pendidik adalah sosok yang bertanggung jawab secara penuh dalam mengembangkan kepribadian peserta didik selama berada di lingkungan Madrasah. Kemudian bukan hanya pendidik saja yang mempunyai peran penting dalam menanamkan nila-nilai karakter melainkan juga melibatkan berbagai pihak seperti orang tua, masyarakat dan lingkungan (Wawancara dengan Pendidik Akidah Akhlak MTs Miftahul ‘Ulum Kecamatan Cipatat, Atep Nandang, S.Pd.I. pada tangal 30 April 2021).

Sehingga tujuan pendidikan karakter dalam meningkatkan mutu menyelenggarakan dan hasil pendidikan yang mengarah pada pencapaian pembentukan akhlak dan etika mulia secara utuh terpadu dan berimbang sesuai standar kompetensi lulusan dapat tercapai (Mahbubi, 2012).

Dalam pelaksanaannya pendidikan karakter menyangkut tiga komponen penting yang saling berkaitan satu sama lain, yaitu: madrasah, keluarga, dan masyarakat. Pendidikan karakter di madrasah dapat diupayakan dalam bentuk pembudayaan kegiatan harian yang khas sesuai dengan visi dan misi madrasah. Sedangkan di kelas, pendidikan karakter dapat dipadukan dengan setiap mata pelajaran. (Kesuma et al., 2011)

Menurut penulis, pendidik mata pelajaran akidah Akhlak bersama-sama para pendidik yang lain dapat merancang berbagai aktivitas sehari-hari bagi peserta didik di Madrasah dengan nilai-nilai ajaran agama. Dan diharapkan peserta didik terbiasa untuk melakukan aktivitas-aktivitas positif yang pada akhirnya dapat membentuk karakter peserta didik tersebut.

Dalam dunia pendidikan, dewasa ini lazim dikenal media pembelajaran yang digunakan sebagai alat bantu mengajar bagi para pendidik untuk memudahkan para siswa didik memahami materi yang diajarkan oleh sang pendidik tersebut, sehingga pendidik tidak hanya mengandalkan komunikasi langsung dan tidak langsung, ataupun komunikasi non verbal beserta perbedaan komunikasi verbal dan nonverbal. Pemakaian media pembelajaran, tidak datang secara tiba-tiba, alias melalui beberapa proses tertentu yang dapat kita pelajari untuk memahami media pembelajaran secara lebih utuh dan menyeluruh dan juga bersinggungan dengan keharusan untuk memahami komunikasi 
multimedia. Sebagaimana yang kita lakukan ketika mempelajari berbagai macam bentukbentuk komunikasi yang ada di sekitar kita.

Setelah adanya perubahan pada asumsi dasar mengenai pentingnya alat bantu penyampaian gagasan kepada siswa, akan tetapi faktor siswa sendiri belum begitu dianggap penting dalam dunia pendidikan. Akan tetapi pada 1960an, para ahli mulai memperhatikan siswa sebagai komponen utama dalam pembelajaran. Pada saat itu teori Behaviorisme yang digagas oleh BF. Skinner mulai mempengaruhi penggunaan media dalam kegiatan pembelajaran. Teori Behaviorisme mendorong diciptakannya media yang dapat mengubah tingkah laku siswa sebagai hasil proses pembelajaran. Produk media pembelajaran yang dilandasi oleh teori ini adalah diciptakannya teaching machine (mesin pengajaran) dan programmed instruction (pembelajaran terprogram).

Pada tahun 1965-1970, pendekatan sistem (system approach) juga mulai menampakkan pengaruhnya dalam dunia pendidikan dan pengajaran. Pendekatan sistem kemudian mendorong digunakannya media sebagai bagian integral dalam proses pembelajaran. Media tidak lagi dipandang sebagai alat bantu pendidik, akan tetapi merupakan bagian tersendiri yang penting dalam proses pembelajaran. Setiap program pembelajaran harus direncanakan secara sistematis dengan memusatkan perhatian pada siswa.

Program pembelajaran direncanakan berdasarkan kebutuhan dan karakteristik siswa didik yang diarahkan kepada perubahan tingkah laku siswa sesuai dengan tujuan yang dicapai. Perlahan-lahan, dari pengalaman yang dialami dari proses tersebut, pendidik mulai menemukan bahwa cara belajar siswa itu berbeda-beda, sebagian ada yang lebih cepat belajar melalui media visual, sebagian audio, media cetak, dan sebagainya. Sehingga dari sinilah lahir konsep media pembelajaran. Pada era komunikasi modern, media komunikasi modern termasuk media pembelajaran perkembangan sangat luas, mulai dari video, VR (Virtual Reality), permainan interaktif, media sosial dengan ciri ciri media sosial yang unik, dan lain sebagainya.

Pemanfaatan pembelajaran dengan menggunakan multimedia menjadi suatu solusi dalam peningkatan kualitas pembelajaran yang dilakukan di kelas, dan menjadi suatu alternatif mengatasi keterbatasan kesempatan mengajar yang dilaksanakan pendidik. Selain 
itu, fungsi multimedia pembelajaran sebagai sumber belajar yakni penyalur, penyampai, penghubung, dan lain-lain. Multimedia pembelajaran sebagai penghubung pembelajaran mampu mengefektifkan proses komunikasi sehingga tercapai tujuan yang diinginkan yaitu degan adanya perubahan tingkah laku siswa.

Diperlukan pula pemanfaatan media yang efektif dalam penyampaian informasi. Media berbasis teknologi informasi dapat dijadikan sebagai pilihan untuk menyampaikan pesan kepada peserta didik. Jika dulu pesan-pesan disampaikan dengan mengandalkan model ceramah dan hafalan, maka saat ini banyak fasilitas teknologi yang dapat dimanfaatkan untuk memediasi pendidik dalam menyampaikan informasi salah satunya adalah film.Film atau gambar hidup merupakan gambar-gambar dalam frame di mana frame demi frame diproyeksikan melalui lensa proyektor secara mekanis, sehingga pada layar terlihat gambar itu hidup. Film bergerak dengan cepat dan bergantian, sehingga memberikan visual yang kontinyu.

Salah satu film yang banyak memuat pendidikan nilai-nilai karakter dan telah di implementasikan di kelas VIII MTs. Miftahul ‘Ulum dan MTs. Asy-Syifa Kecamatan Cipatat Kabupaten Bandung Barat adalah film Kisah Nabi Muhammad SAW. Beberapa potongan film Kisah Nabi Muhammad SAW telah digunakan dalam proses pembelajaran terutama dalam pembelajaran nilai-nilai akhlak yang sangat mendukung penanaman lima nilai pendidikan karakter yang telah disusun oleh kementerian pendidikan nasional, yaitu: religius, nasionalis, mandiri, gotong royong, dan integritas.

Hal inilah yang mendasari penulis untuk mengetahui gambaran bagaimana Implementasi Pendidikan Karakter melalui Media Film Dalam Pembelajaran Akidah Akhlak di Kelas VIII MTs. Miftahul ‘Ulum dan MTs. Asy-Syifa Kecamatan Cipatat Kabupaten Bandung Barat.

\section{METODOLOGI}

Penelitian ini menggunakan pendekatan kualitatif dengan metode deskriptif analitis tentang Implementasi Pendidikan Karakter melalui Media Film Dalam Pembelajaran 
Akidah Akhlak di Kelas VIII MTs. Miftahul ‘Ulum dan MTs. Asy-Syifa Kecamatan Cipatat Kabupaten Bandung Barat. Jenis data dalam penelitian ini yaitu data yang disajikan dalam bentuk verbal yang dinarasikan lewat kata-kata. Sumber data dalam penelitian ini adalah Kepala sekolah, guru akidah akhlak, staf tata usaha, siswa dan orang tua di rumah. Adapun pengumpulan data dalam penelitian ini mengunakan observasi, wawancara, dan dokumentasi. Data dianalisis melalui tahapan reduksi data, penyajian data, penarikan kesimpulan, dan uji keabsahan datanya dengan triangulasi).

\section{HASIL DAN PEMBAHASAN}

Hasil penelitian dan pembahasan ini telah dipaparkan di lapangan melalui proses seleksi data yang telah ditemukan baik data dokumentasi, wawancara maupun data observasi lapangan. Maka pada bab pembahasan ini, temuan tersebut akan dianalisis untuk merekonstruksikan konsep yang didasarkan pada teori empiris yang sudah ada pada Bab kajian teori. Untuk lebih jelasnya maka dapat dilihat pada pemaparan di bawah ini :

Perencanaan pendidikan karakter melalui Media Film Dalam Pembelajaran Akidah Akhlak

Perencanaan pembelajaran merupakan langkah awal yang sangat penting dan menentukan proses-proses atau tahapan selanjutnya yang diharapkan bermuara pada tujuan pembelajaran yang hendak dicapai. Sebelum guru melakukan proses pembelajaran di dalam kelas, maka guru harus memiliki perencanaan dan persiapan yang matang agar proses pelaksanaan pembelajaran dapat berkualitas dan berjalan sesuai dengan harapan.

Kesiapan guru dalam mengajar dimulai dengan penyiapan perangkat administrasi pembelajaran berupa Silabus, Program Tahunan, Program Semester, Analisis KKM, dan Rencana Pelaksanaan Pembelajaran (RPP). Guru harus menunjukkan dokumen perencanaan pembelajaran yang akan dilaksanakan dalam proses pembelajaran di dalam kelas.

Perencanaan pembelajaran yang disusun oleh guru di MTs Miftahul ‘Ulum dan MTs. Asy-Syifa dituangkan dalam desain kurikulum dan langkah-langkah pembelajaran yang sistematis mulai dari tahap pendahuluan, kegiatan inti pembelajaran, dan penutup. Langkah-langkah ini dirumuskan secara detail melalui RPP berdasarkan kurikulum 2013. 
Desain pembelajaran di dalam RPP dirancang berdasarkan metode pembelajaran yang dipilih oleh guru. Metode pembelajaran yang disarankan dalam implementasi kurikulum 2013 terdiri atas empat metode, yaitu: (1) metode inkuiri atau descovery learning; (2) problem based learning; (3) project based learning; dan (4) metode saintifik. Pemilihan salah satu metode pembelajaran mengharuskan guru menerapkan sintak pembelajaran yang sesuai dengan metode tersebut. Namun, semua metode yang digunakan ini mengharuskan guru untuk mengarah pada pembelajaran aktif atau pembelajaran yang berpusat pada peserta didik (Retno, 2012).

Berdasarkan pernyataan tersebut dapat dipahami bahwa salah satu bentuk perencanaan yang dilakukan oleh guru Akidah Akhlak sebelum melakukan proses pembelajaran adalah dengan mempersiapkan media pembelajaran berupa film yang berisi nilai-nilai karakter yang sejalan dengan materi Akidah Akhlak. Salah satu film yang dipilih oleh guru Akidah Akhlak sebagai media pembelajaran adalah film Kisah Nabi. Film Kisah Nabi ini dipilih karena konten atau isi film tersebut banyak mengandung aksi, sikap, tindakan, dan pesan-pesan moral yang dapat dijadikan contoh yang baik dalam menerapkan karakter.

Pembelajaran yang bersifat symbolic atau yang bersifat abstrak dalah modus pembelajaran yang lebih bersifat tekstual atau penjelasan verbal yang diterima oleh peserta didik (Zainiyati, 2017). Film dimanfaatkan dalam berbagai keperluan baik yang bersifat informatif, hiburan, maupun pendidikan. Dalam dunia pendidikan film dapat dijadikan sebagai media yang sangat membantu guru dalam menyampaikan materi pembelajaran atau pun untuk keperluan penguatan materi pembelajaran. Banyak materi pembelajaran yang bila dijelaskan secara verbal kurang atau sulit dipahami oleh peserta didik. Sehingga guru dituntut untuk merencanakan dan mengupayakan media pembelajaran yang memudahkan peserta didik memahami sebuah konsep melalui sebuah tayangan visual.

Pendidikan budaya dan karakter bangsa bisa dipahami sebagai proses penanaman nilai-nilai budaya dan karakter yang luhur kepada generasi muda yang kemudian diterapkan dalam kehidupan sosial, berbangsa dan bernegara (Hasan \& Wahab, 2010). Karakter dapat dibagi menjadi karakter baik dan karakter buruk. Orang yang berperilaku jujur, toleran, menghargai orang lain misalnya, adalah ciri utama karakter yang baik. 
Sebaliknya, orang yang berperilaku tidak jujur, kejam terhadap sesamanya bisa dikatakan sebagai orang yang memiliki karakter yang buruk. Dengan penjelasan ini bisa dipahami bahwa persoalan karakter sangat erat kaitannya dengan personalitas .

Implementasi pendidikan karakter melalui Media Film dalam pembelajaran akidah akhlak

Implementasi adalah suatu proses, suatu aktivitas yang digunakan untuk mentransfer ide atau gagasan, program atau harapan-harapan yang dituangkan dalam bentuk kurikulum desain (tertulis) agar dilaksanakan sesuai dengan desain tersebut. Masing-masing pendekatan itu mencerminkan tingkat pelaksanaan yang berbeda. Dalam kaitannya dengan pendekatan yang dimaksud, Nurdin menjelaskan bahwa pendekatan pertama menggambarkan implementasi itu dilakukan sebelum penyebaran (desiminasi) kurikulum desain. Kata proses dalam pendekatan ini adalah aktivitas yang berkaitan dengan penjelasan tujuan program, mendeskripsikan sumber-sumber baru dan memaparkan metode pengajaran yang digunakan (Usman, 2002).

Implementasi pendidikan karakter dalam lingkungan sekolah sangatlah penting dan mendesak dilakukan mengingat tantangan perubahan yang sangat dinamis. Peserta didik perlu dibekali oleh nilai-nilai karakter yang sesuai dengan nilai-nilai agama dan budaya yang dianut masyarakat. Tantangan perubahan zaman ini sangat terasa mengingat determinasi kemajuan teknologi informasi yang sangat masif mempengaruhi kehidupan masyarakat hingga ke tingkat bawah. Perhatian terhadap program penguatan karakter dapat dilihat dari berbagai kebijakan dan program sekolah yang mengarah pada penguatan pendidikan karakter yang telah dikuatkan dan diimplementasikan. MTs. Miftahul 'Ulum dan MTs. Asy-Syifa sendiri telah menerapkan berbagai kegiatan dan program keagamaan yang bermuara pada penguatan sikap dan karakter peserta didik. Program keagamaan sendiri sangatlah mendukung penguatan pendidikan karakter karena salah satu fondasi terbangunnya pendidikan karakter adalah melalui pendidikan keagamaan.

Menurut Hanifah yang telah dikutip oleh Hadayani telah mengemukakan pendapatnya implementasi adalah "suatu proses untuk melaksanakan kegiatan menjadi tindakan kebijakan dari politik kedalam administrasi. Pengembangan suatu kebijakan dalam rangka penyempurnaan suatu program. Guntur Setiawan mengemukakan 
pendapatnya implementasi adalah "perluasan aktivitas yang saling menyesuaikan proses interaksi antara tujuan dan tindakan untuk mencapainya serta memerlukan jaringan pelaksana, birokrasi yang efektif"' (Handayani, 1970).

Implementasi film Kisah Nabi dalam proses pembelajaran Akidah Akhlak di MTs. Miftahul ‘Ulum dan MTs. Asy-Syifa mengarah pada penerapan metode pembelajaran yang ada di dalam kurikulum 2013. Metode pembelajaran dalam kurikulum 2013 mengisyaratkan bahwa langkah-langkah pembelajaran yang dilaksanakan harus dimulai dengan proses pemberian rangsangan atau stimulus kepada peserta didik berupa penayangan media film yang dapat mengantar pemahaman peserta didik terhadap materi. Setelah itu peserta didik diminta memberikan komentar atau memberikan pertanyaan berkaitan dengan tayangan yang telah disampaikan oleh guru dan hal- hal lain yang berkaitan dengan pemahaman terhadap materi pembelajaran. Lalu peserta didik mengerjakan tugas yang berkaitan dengan pertanyaan yang telah diajukannya.

Dampak implementasi pendidikan karakter melalui media film dalam pembelajaran akidah akhlak

Pendidikan karakter yang diintegrasikan dalam proses pembelajaran Akidah Akhlak dengan menggunakan media film memberikan dampak yang sangat baik dalam dua ranah utama, yaitu dampak dalam proses pembelajaran di dalam kelas dan dampak di luar proses pembelajaran. Kedua bagian ini merupakan buah dari implementasi proses pembelajaran Akidah Akhlak yang didesain secara menarik oleh guru dengan menghadirkan tayangantayangan yang sejalan dengan materi yang diajarkan.

Dampak implementasi pendidikan karakter melalui media film di MTs. Miftahul 'Ulum dan MTs. Asy-Syifa dapat dilihat dalam kegiatan pembiasaan jangka pendek, jangka menengah, dan jangka panjang dengan kriteria atau indiktor sebagai berikut :

a. Siswa memahami, menerima dan menerapkan prinsip-prinsip pendidikan karakter sehingga berpengaruh terhadap cara berpikir,bersikap dan berprilaku dalam kehidupan sehari-hari.

b. Siswa mendapat kemudahan dalam belajar dan memeiliki kemauan belajar yang tinggi

c. Siswa berpartisipasi secara aktif dalam pembelajaran sehingga terbentuk sikap jujur, tanggung jawab, disiplin,santun, peduli dan percaya diri sebagai suatu pembiasaan. 
Pembiasaan adalah sesuatu yang sengaja dilakukan secara berulang-ulang agar sesuatu itu dapat menjadi kebiasaan. Metode pembiasaan ini berintikan pengalaman. Karena yang di biasakan itu ialah sesuatu yang diamalkan. Dan inti kebiasaan adalah pengulanagn. Pembiasaan menempatkan manusia sebagai sesuatu yang istimewah, yang dapat menghemat kekuatan, karena akan menjadi kebiasaan yang melekat dan spontan, agar kegiatan itu dapat di lakukan dalam setiap pekerjaan. Oleh karenanya, menurut para pakar, metode ini sanagt efektif dalam rangka pembinaan karakter dan kepribadian anak. Orang tua membiasakan anak-anaknya untuk bangun pagi. Maka bangun pagi itu akan menjadi kebiasaan (Gunawan, 2012).

Faktor pendukung dan penghambat implementasi pendidikan karakter melalui media film dalam pembelajaran akidah akhlak

Pengejawantahan nilai-nilai karakter dalam kehidupan sehari-hari peserta didik mengarah pada dua ranah yang saling bertaut. Berbudi luhur merupakan karakter mulia yang secara substantif akan memberikan penghargaan pada diri seseorang. Sementara bersikap murah hati adalah nilai yang sangat membantu seseorang dalam menjalin hubungan baik dengan sesama manusia karena sikap ini membangun kesadaran sosial yang sangat arif. Bahkan menurut Lickona, karakter itu memiliki nilai yang bersifat operatif, nilai dalam tindakan. Tindakan yang dilakukan oleh seseorang sebenarnya adalah respons terhadap aspek di luar dirinya berdasarkan penilaian terhadap nilai-nilai karakter yang positif yang dipandang oleh seseorang sebagai nilai baik dan positif. Dengan begitu ada tiga proses yang perlu menjadi perhatian dalam tahap pengembangan karakter, yaitu: pengetahuan moral, perasaan moral, dan perilaku moral (Lickona, 2012).

Berdasarkan hasil wawancara dengan civitas akademika di MTs. Miftahul ‘Ulum dan MTs. Asy-Syifa bahwa, implementasi pendidikan karakter melalui media film tidak terlepas dari faktor-faktor yang mempengaruhi, baik faktor pendukung maupun faktor penghambat. Faktor-faktor tersebut diantaranya, yaitu :

a. Faktor Pendukung

Faktor pendukung yang dapat mempengaruhi dalam implementasi pendidikan karakter melalui media film dalam pembelajaran akidah akhlak di MTs. Miftahul ‘Ulum dan MTs. Asy-syifa diantaranya sebagai berikut : 
a) Faktor Guru

Faktor ini mempunyai pengaruh yang sangat besar terhadap kualitas pembelajaran yang meliputi kemapuan dasar yang dimiliki oleh guru, baik kognitif (pengetahuan) seperti penguasaan bahan, keteladanan, sikap mencintai profesinya dan prilaku seperti keterampilan mengajar, menilai hasil belajar dan lain sebagainya.

b) Faktor Peserta Didik

Hal yang dapat mempengaruhi kulaitas pembelajaran yaitu datang dari peserta didik sendiri diantaranya kemampuan peserta didik, motivasi belajar. Minat, perhatian, sikap dan kebiasaan belajar dan beribadah.

C) Partisipasi orang tua

Partisipasi orang tua terhadap sekolah melalui komite sekolah yang sangat baik. Serta faktor lingkungan yang sangat mempengaruhi. Jika tidak ditunjang oleh lingkungan yang kondusif, upaya pendidikan karakter disekolah disekolah akan seperti membuat istana pasir di tepi pantai artinya di sekolah, kepala sekolah, guru, beserta tenaga kependidikan lainnya dengan sekuat tenaga membangun istana yang cantik, tetapi ketika anak keluar dari lingkungan sekolah, ombak besar mmeluluhlantakhan istana yang telah dibangun tersebut.oleh karena itu perlu pendekatan yang komprehensif dari sekolah, keluarga dan masyarakat dalam mengembangkan karakter peserta didik yang kuat, baik dan positif secara konsisten.

b. Faktor Penghambat

a) Pola prilaku siswa yang terkadang sulit diatur

Di sekolah guru berperan utama untuk mengatur setiap kegiatan siswa di dalam maupun di luar kelas. Tidak dipungkiri bahwa tidak semua siswa sudah memiliki karakter yang diharapkan, maih ada beberapa siswa yang masih melakukan perbuatan yang tidak diharapkan misalnya membuang sampah sembarangan, mecorat-coret meja dan kursi atau berkata tidak santun kepada temannya maka hal ini menjadi tanggung jawab semuanya untuk memperbaiki prilaku yang tidak diharapkan tersebut. 
b) Sarana dan prasarana yang tidak terjaga

Saran dan prasarana merupakan penunjang untuk tercapainya tujuan pendidikan yang diharapkan. Dengan tujuan untuk mengembangkan kepribadian siswa di sekolah.yang seharusnya terjaga dengan baik, akan tetapi, ada beberapa siswa yang tidak mau menjaga kebersihan dan tidak mau menjaga saran prasarana yang ada di sekolah, misalnya, meja, kusri, dan tembok dinding yang di coret-coret.

c) Keterbatasan waktu di sekolah

Waktu belajar di sekolah yaitu enam hari kerja, penganturan waktu efektif pembelajaran dimulai $07.00 \mathrm{Wib}$ dan berakhir $13.00 \mathrm{Wib}$ dengan jadwal pembelajaran yang padat, sehingga hal ini menjadi penghambat untuk melaksanakan pembinaan bagi siswa yang memiliki perhatian khusus dalam perbaikan sikap dan prilakunya.

d) Kesibukan orang tua

Pengaruh kemajuan ilmu pengetahuan dan teknologi serta pola hidup yang materialistis dan pragmatis menyebabkan orang tua selalu disibukan dengan karir masiing-masing, sehingga mereka tidak sempat memberikan perhatian dan pendidikan dan kasih sayang kepada anak-anaknya serta tidak memperhatikan pendidikan agama khususnya pendidikan akahlak anaknya.

e) Faktor pengaruh lingkungan yang kurang baik

Interaksi anak dengan lingkungan tidak dapat dielakan, kareena anakmembutuhkna teman bermain dan kawan sebaya untuk bisa diajak bicara sebagai bentuk sosialisasi. Lingkungan rumah dan lingkungan pergaulan anak yang jauh dari nilai-nilai agama lambat laun dapat melenurkan pendidikan agama khususnya pendidikan akahlak yang telah ditanamakan di rumah maupun sekolah.

f) Faktor media masa dan media sosial

Kemajuan ilmu pengetahuan dan teknologi telah menciptakan perubahan besar dalam kehidupan ini. Media masa dan media sosial lain terkadang lebih banyak memberikan dampak negatif kepada perkembangan anak terutama terhadap pembentukan pribadi dan karakter anak. 


\section{PENUTUP}

Simpulan akhir dari penelitian ini secara umum, bahwa dalam pembelajaran Aqidah Akhlaq di MTs. Miftahul 'Ulum dan MTs. Asy-syifa, peranan media sangat penting dan strategis. Media sebagai segala wujud yang dapat dipakai sebagai sumber belajar yang dapat merangsang pikiran, perasaan, perhatian, dan kemauan peserta didik sehingga mendorong terjadinya proses belajar mengajar ketingkat yang lebih efektif dan efisien. Dalam konteks ini dapat dikemukakan bahwa urgensi penerapan media pembelajaraan dapat mempengaruhi karakter dan sikap peserta didik terhadap proses dan hasil belajar. Penelitian ini bertolak dari problematik bagaimana upaya yang dapat dilakukan untuk mengefektifkan penerapan media pembelajaran agar dapat meningkatkan karakter belajar peserta didik. Khususnya perlu kiranya untuk dapat memilah dan memilih media yang sesuai untuk dijadikan model dalam penanaman pendidikan karakter dalam proses pembelajaran. Para Pendidik harus dibangun keaktifan dan kekreatifannya dalam menyajikan berbagai pemanfaatan media pembelajaran untuk meningkatkan karakter belajar peserta didik, dan mengambil nilai-nilai penting sehingga keefektifan media pembelajaran dalam meningkatkan karakter belajar peserta didik dapat berdampak positif..

\section{DAFTAR PUSTAKA}

Gunawan, H. (2012). Pendidikan karakter konsep dan implementasi. Alfabeta.

Handayani, M. A. (1970). Studi Peran Film dalam Dunia Pendidikan. INSANIA : Jurnal Pemikiran Alternatif Kependidikan, 11(2), 176-186. https://doi.org/10.24090/insania.v11i2.166

Hasan, S. H., \& Wahab, A. A. (2010). Pengembangan pendidikan budaya dan karakter bangsa. Bahan Pelatihan Penguatan Metodologi Pembelajaran Berdasarkan Nilai-Nilai Budaya Untuk Membentuk Daya Saing Dan Karakter Bangsa, 7.

Kesuma, D., Triatna, C., \& Permana, J. (2011). Pendidikan karakter: kajian teori dan praktik di sekolah. Remaja Rosdakarya.

Lickona, T. (2012). Mendidik untuk Membentuk Karakter.(Terjemahan Juma Abdu Wamaungo). Bumi Aksara.

Mahbubi, M. (2012). Pendidikan karakter: implementasi aswaja sebagai nilai pendidikan karakter. Pustaka Ilmu Yogyakarta.

Retno, L. (2012). Pendidikan Karakter dalam Metode Aktif, Inovatif, dan Kreatif. Esensi Erlangga 
Group.

Usman, N. (2002). Konteks implementasi berbasis Kurikulum. Raja Grafindo Persada.

Zainiyati, H. S. (2017). Pengembangan Media Pembelajaran Agama Islam Berbasis ICT. Kencana. 